\title{
HTR2A 1 Allele
}

National Cancer Institute

\section{Source}

National Cancer Institute. HTR2A 1 Allele. NCI Thesaurus. Code C45685.

HTR2A-C Allele is a variant form of 20-kb 3-exon human HTR2A Gene (GPCR1/5HT2

Family), which encodes Serotonin 5-HT-2A Receptor, a conserved integral membrane 5-

HT/serotonin receptor protein involved in tracheal smooth muscle contraction, bronchoconstriction, and control of aldosterone production by association with $\mathrm{G}$ proteins that activate a $\mathrm{PI}$-calcium second messenger system. 5 - $\mathrm{HT}$ is a biogenic hormone that affects specific receptors as a neurotransmitter, hormone, or mitogen. HTR2A contains several polymorphic sites. Different alleles differ in the concentration of RNA and protein product of 5HTR2A. HTR2A-C Allele contains a single-nucleotide polymorphism (102 T>C) in an intron and is expressed at a lower level than the $102 \mathrm{C}>\mathrm{T}$ allele. 